\title{
Grammatical Errors on EFL Students' Conversation Practice: Surface Strategy Taxonomy
}

\author{
Resti Citra Dewi ${ }^{1}$, Fitria Hardini Rangkuti ${ }^{2}$, Supriadi ${ }^{3}$ \\ ${ }^{1}$ Indonesia Institute of Technology and Business, Indonesia \\ ${ }^{2}$ Indonesia Institute of Technology and Business, Indonesia \\ ${ }^{3}$ STKIP Al Maksum, Indonesia
}

Corresponding Author $\otimes$ citradewiresti@rocketmail.com

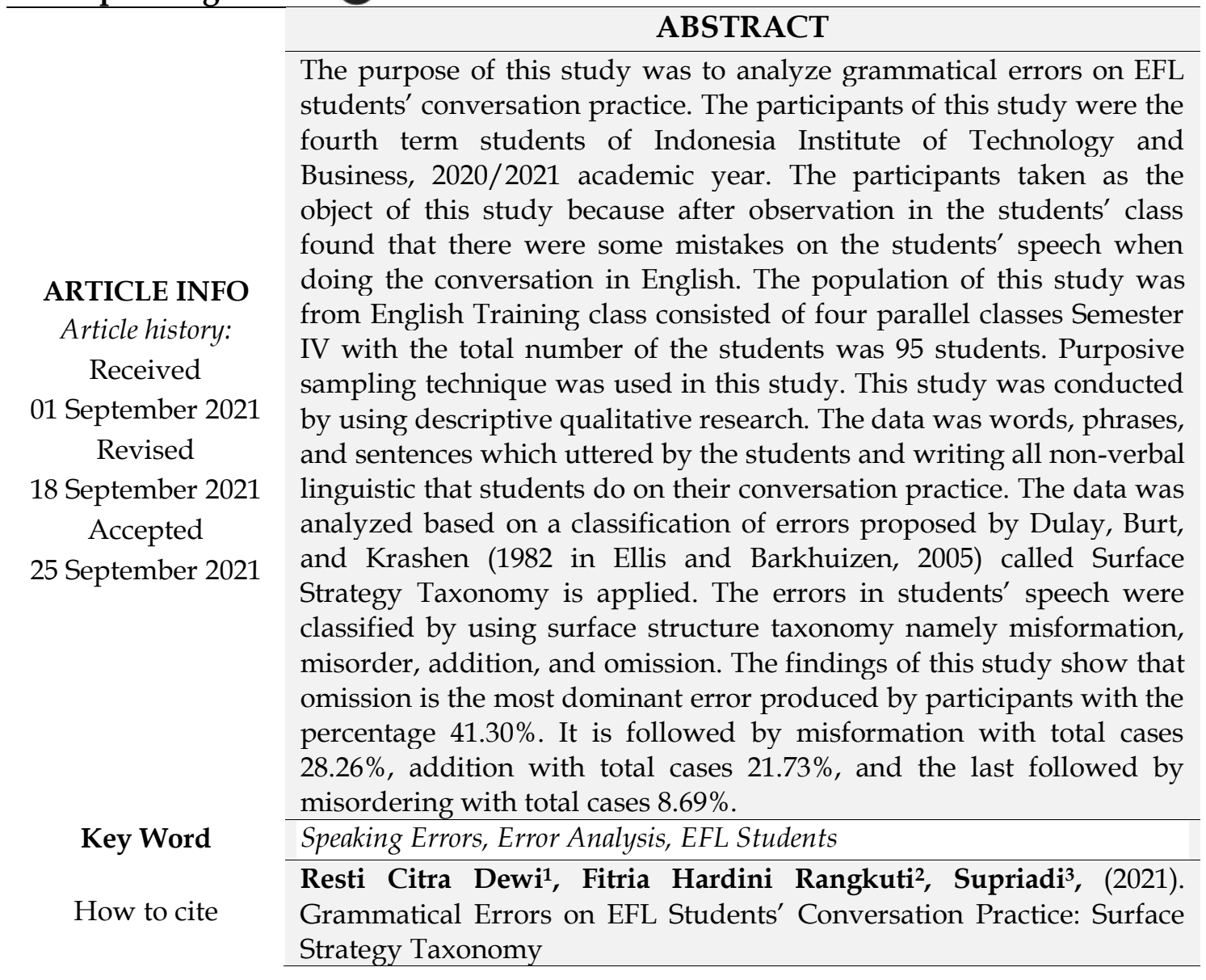

\section{INTRODUCTION}

There are some goals of learning English as A Foreign Language (EFL) which one of the most crucial goals is able to speak English well and fluently (Ruminar, 2018). A parameter to measure the success in learning English as a foreign/second language is competence in spoken English. This perspective comes because the basic function of language is to communicate (Srivastava, 2014). Therefore, using appropriate words grammatically especially in speaking English affects to the understanding of the hearer. It will make the hearer catch the speaker's idea easily from the speech as it is noted that delivering idea or message is the main goal of speaking. Using correct words and grammar in speaking can also be analyzed by using rubrics of scoring speaking which it will be focused in this study. It gives contribution with certain percentage in assessing speaking. In other words, grammar takes its crucial part in producing 
the speech. It is necessary or students learn more about English grammar and it is suggested for teacher to re-teaching about verb agreement and pronoun (Royani \& Sadiah, 2019).

When the researcher taught at Indonesia Institute of Technology and Business (ITB Indonesia) found out that there were some students' problems in their conversation practice when they did in their video conversation. So the researcher found there were some reasons to write this study. The first reason is the students had difficulties in learning English especially at speaking. The students got low score and they needed to do some remedial conversation practice. Most students find some difficulties when they are needed to practice orally, especially in English. The problem arose because English is still foreign for them. Conversation practice is a speech that needs a script. Hence, in conversation practice is considered that the language accuracy is needed. The second reason is because speaking is important in order communication can run well. The third reason is the researchers could know the weaknesses of the students especially in grammatical error. So the researcher is able to determine the effective way how to encourage the students to do role play on their conversation practice. So based on these reasons, the researchers were interested to choose the title as the research.

In analyzing grammatical error proposed by Burt, Dulay, and Krashen (1982) is called Surface Structure Taxonomy, namely misformation, misorder, addition, and omission. Firstly, misformation errors means the learners use a wrong form or structure. There are three kinds of misformation error, namely regularization, archi-form, and alternating forms. Secondly, misorder means the incorrect placement of a morpheme or group of morphemes in an utterance. Thirdly, addition means when the presence of an item that must not appear in wellformed utterances. Errors of addition are divided into three parts, namely regularization, double marking, and simple addition. Fourthly, omission is the absence of an item that must appear in a well-formed utterance. In classifying the types of errors on students' oral conversation practice, this study used the types of error in the surface structure taxonomy by Burt, Dulay, and Krashen (1982), namely omission, addition, misformation, and misordering.

The researcher conducts a research on analyzing the grammatical errors on EFL students' conversation practice by utilizing the surface structure taxonomy based on theory from Burt, Dulay, and Krashen (1982). The college students at Indonesia Institute of Technology and Business (ITB Indonesia) has English Training Program in 2020/2021 academic year. So, based on the background explained above, the research questions of the study are formulated as follows:

1) What the grammatical errors are uttered by the EFL students' conversation practice?

2) Which the most dominant grammatical errors are uttered by the EFL students' conversation practice?

One type of error analyses had been added which is called Blends according to James (1998:111). Error of blends occurs when the learner has used two structures that are semantically related each other, either which could serve his present purpose, or they fail to make a distinct choice, and instead of combining a part of each to produce a structure which characteristics of both. For example, the use of the word one and each in a phrase: "for each one thing". The last type of error is called miscellaneous errors. The surface structure taxonomy or blends does not belong to miscellaneous errors. Miscellaneous errors are kinds of errors in conjunction with translation, not correct order and choice of English words in term of the meaning of the sentence in context as well as the omission or addition of certain language elements, Simbolon (2015). 
Grammatical errors across proficiency levels collected from ESP class show that the errors in the students' speech classified by using surface structure taxonomy were indicated that misformation is the dominant error produced by both levels of proficiency. It is followed by omission, addition, miscellaneous, misorder and blends (Ruminar, 2018). In another research founded that errors of verb in the learners' writing production reveal that the learners' errors encompass three types of four aforementioned, i.e. addition, omission, and misformation. Whereas misordering was not identified among the learners' errors on paragraph composition, eventually, a pedagogical implication as a result of the research was made (Rusmiati, 2019). In addition, (Wati \& Nursyaebah, 2017) found that there are six classifications of grammatical error; those are verb agreement, capitalization usage, sentence pattern pronoun and spelling.

According Suhono (2016) in his analysis on composition written by EFL Students IAIM NU Metro. It aims at developing further analyzing of error analysis in second language learners. He analyzed the types of grammatical errors made by the participants at different grade by using surface strategy taxonomy theory. It revealed that many sentences indicated errors. Types of omission error was the highest one. Furthermore, in the other grade grammatical error was the highest one. The sources of errors of the research were mothertongue influence (Interlingual errors). It was affected by the native language which obstructs with target language learning. The second was Intralingual errors, caused by the target.

In writing errors based on surface structure taxonomy which a case of indonesian efl students' personal letters, Maolida \& Hidayat (2021) indicate that the students are unaware of the existence of different rules in using English, especially in the written form. Making errors is, somehow, a main part of learning new language. It means the teachers may use the information from the errors as an authentic source to evaluate students' writing proficiency. Moreover, identifying students' writing problems tells the way for the teachers to unfurl the appropriate solutions to solve the problems. Considering those, this research was conducted to discover students' writing errors, classify them to the surface structure taxonomy proposed by Dulay, Burt, Krashen (1982) and James (2013), and further identify most dominant type of error. The experts have categorized the error into four elements namely, omission, addition, misformation and misordering.

\section{RESEARCH METHODS}

This study employed descriptive qualitative method since the goal was to reveal or explain types of error based on surface structure taxonomy and the type that is frequently appeared. The authors used the framework of surface structure taxonomy proposed by Dulay, Burt and Krashen (1982) and which categorized errors into four types. The first type is omission with two subtypes namely, grammatical morphemes and content morphemes. Secondly is the addition which is categorized into three types namely, simple addition errors, double-marking errors, and regularization errors. Misformation, as the third type, which consists of three sub-types such as regularization, archi-form, and alternative form. Then, misordering type which is categorized into seven such as misplacement of verbs, misplacement of objects, misplacement of adverbs, misordering in question formation, wrong placement of modifiers, wrong placement of not, and misplacement of items/constituents in a structure.

The population of this study was from English Training class consisted of four parallel classes of all departments of Indonesia Institute of Technology and Business (ITB Indonesia) with the total number of the students was 95 students, 2020/2021 academic year. In order to get representative data, purposive sampling technique was used in this study. In addition, the aim 
of selecting these participants was because they had English Training class for ten meetings in one term (six months) which they studied about how to give a good conversation in English with different topics. It took about 2 months to collect and analyse the data. The data of this study was words, phrases, and sentences which uttered by the students and writing all nonverbal linguistic that students do on their conversation practice, which was acquired from an assignment given by the lecturer during the English Training. From the data, the authors obtained the fact that students committed errors in their conversation practice. The lecturers limited the topics of the conversation practice. This was done in order to get variative data without having to minimize the students' creativity. The topics which was given are small talks, entertaining visitor, health, shopping, helping customers and coleagues, and services. After the students got explanation about the topics, they made a conversation by using video recording.

The data were collected by obcervation, interview, transcripts, field notes, video recordings, personal documents, memos, and other official records to know the utterances uttered by the EFL students' conversation practice and classified their types of grammatical error.

In analysing the data the authors adopted the six stages proposed by Sridhar (1980) in Fauziati (2014). The first stage is collection of data that has been explained previously. The second stage is identification of errors by labelling and moving the errors utterance into a table. Next, the third stage is classification into error types. The authors classified the errors into their types, by marking ' $x$ ' on each category in the table. The fourth stage is statement of relative frequency of error types. Thereafter, the authors identified the areas of difficulty in the target language. Finally, as a response to the errors uttered by the college students, the author gave them direct feedback.

In calculating the number and frequency of errors, the authors employed the statistical

calculation by Walizer and Wiener (1990) as cited in Aziz et al. (2020), as follows:

$\mathrm{P}=\frac{f}{N} \times 100 \%$

Where

$\mathrm{P}$ is the percentage of errors

$\mathrm{F}$ is the frequency of errors

$\mathrm{N}$ is the total number of samples

\section{RESULT AND DISCUSSION}

The result of this study is presented and discussed based on the theory of errors proposed by Dulay, Burt, and Krashen (1982 in Ellis and Barkhuizen, 2005), it is called Surface Strategy Taxonomy. These theories lead the discussion of the types of errors the college students commit in their conversation practice.

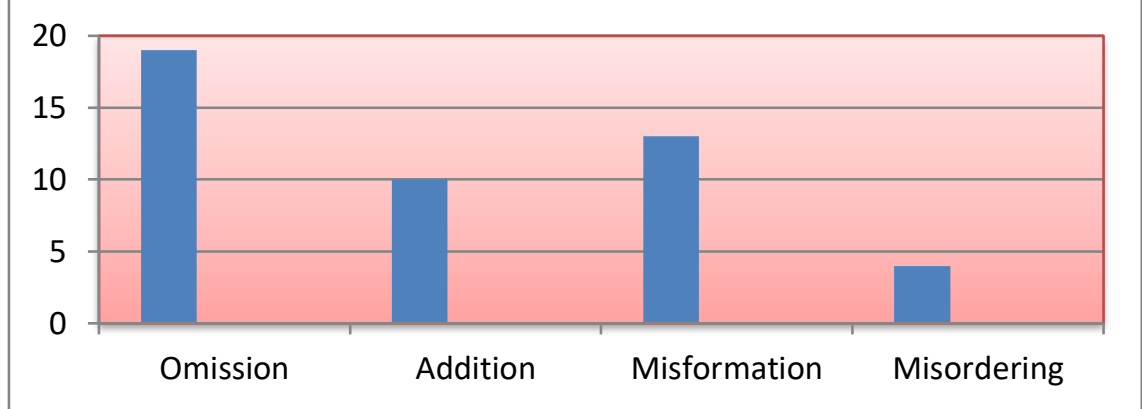

Figure 1. Types of Errors on EFL Students' Conversation practice 
As seen in Figure 1, the omisson error was the most dominant occured in students' conversation practice, with 19-time occurrences, then followed by misformation with 13-time occurrences, next addition with 10-time occurrences, and the last followed by misordering with 4-time occurrences. After collecting and analyzing the data, the authors found there were 46 errors made by EFL students on their conversation practice. Table 1 below shows the details of the type of error, number, and percentage.

Table 1. The Frequency of Error Types Categoriation

\begin{tabular}{|c|c|c|}
\hline Errors Category (Subtypes) & Number & Percentage \\
\hline Omission & 19 & $41.30 \%$ \\
\hline Misformation & 13 & $28.26 \%$ \\
\hline Addition & 10 & $21.73 \%$ \\
\hline Misordering & 4 & $8.69 \%$ \\
\hline Total Error & & \\
\hline
\end{tabular}

Based on Table 1, 41.30\% from 19 data belongs to omission errors as the most committed error. The second most committed errors uttered by EFL students is misformation with $28.26 \%$ total cases. The findings also show 10 addition errors, with $21.73 \%$ total cases. The last, misordering errors occur 4 times out of 46 cases, $8.69 \%$ out of $99.98 \%$ in percentage.

\section{The Omission Errors}

The omission errors are frequently appeared in this study. Omission errors usually occur when the linguistic item required in the sentence is omitted, e.g., She "water the flower. Here the morpheme " $\mathrm{s}$ " is omitted required for the correct constructionof the sentence (Jabeen et al., 2015). So, there are 19 omission errors found on EFL students' conversation practice. Table 2 will present the details.

Table 2. Omission Errors

\begin{tabular}{|c|l|l|}
\hline & \multicolumn{1}{|c|}{ Students' Utterance } & \multicolumn{1}{c|}{ Alternative Correction } \\
\hline \multirow{3}{*}{ Omission Errors } & $\begin{array}{l}\text { I want to buy some } \\
\text { book. }\end{array}$ & I want to buy some books. \\
\cline { 2 - 3 } & Congratulation! & Congratulations! \\
\cline { 2 - 3 } & $\begin{array}{l}\text { You want come with } \\
\text { me? }\end{array}$ & You want to come with me? \\
\hline Total (\%) & \multicolumn{2}{|c|}{$\mathbf{1 9 ( 4 1 . 3 0 \% )}$} \\
\hline
\end{tabular}

Based on the data findings, the omission errors were most dominant uttered by the participants. As seen in the first sample, the EFL student stated "some book" without word "s", whereas in English there are two kinds of noun, namely countable noun and uncountable noun. The word "book" is countable noun, so it requires to add word "-s/-es" to show the plural nouns. Then followed by the second example "congratulation!", in this context the participants express praise for an achievement or good wishes on a special occasion. But the EFL student omit the wrod "s" in this utterances. And lastly, "you want come with me, which is the correct construction is by adding word "to" after verb "want", because verb "want" followed by to infinitive.

\section{The Misformation Errors}

Misformation error is distinguished by the use of the wrong form of the morpheme or structure. Table 3 provide more detail explanation. 
Journal of Education and Teaching Learning (JETL)

Volume 3, No 3, September 2021

Page 10-17

Table 3. Misformation Errors

\begin{tabular}{|c|l|l|}
\hline \multirow{4}{*}{ Misformation Errors } & \multicolumn{1}{|c|}{ Students' Utterance } & \multicolumn{1}{|c|}{ Alternative Correction } \\
\cline { 2 - 3 } & How much this shirt costs? & How much is this shirt? \\
\cline { 2 - 3 } & $\begin{array}{l}\text { You can take this medicine } \\
\text { two times a day. }\end{array}$ & $\begin{array}{l}\text { You can take this } \\
\text { medicine twice a day. }\end{array}$ \\
\hline Total (\%) & \multicolumn{2}{|c|}{$\mathbf{1 3 ( 2 8 . 2 6 \% )}$} \\
\hline
\end{tabular}

Based on the results, the characteristic of this error usually in a form of word misused as seen in Table 3. The first sample showed in Table 3 above, the EFL student didn't use the correct construction, which is to form the interrogative sentence should use the auxiliary verb before the verb, so it must be "How much is this shirt?". Even it is understood in the meaning, but the student didn't use the correct grammatical in this way. The next misformation sample is "where do you will go?" it should be "where will you go", it is the correct way to state the interogative sentence than by adding do anymore, it is not correct interrogative sentence because they are two auxiliaries no needed in that way. And lastly, the student used word "two times" instead of 'twice'.

\section{The Addition Errors}

Addition errors are grammatical errors whch is caused by the presence of a form or an element that must not appear in a well-formed utterance (Tizazu, 2014). Data analysis reveals that 10 out of 46 cases are categorized as addition errors. In Table 4, the authors explained the addition errors in detail.

Table 4. Addition Error

\begin{tabular}{|c|c|c|}
\hline & Students' Utterance & Alternative Correction \\
\hline \multirow{3}{*}{$\begin{array}{l}\text { Addition } \\
\text { Errors }\end{array}$} & It sounds like fun. & It sounds fun. \\
\hline & $\begin{array}{l}\text { We can see the beautiful view } \\
\text { in there. }\end{array}$ & $\begin{array}{l}\text { We can see the beautiful } \\
\text { view there. }\end{array}$ \\
\hline & $\begin{array}{l}\text { Please you're look at the are } \\
\text { sales item. }\end{array}$ & $\begin{array}{l}\text { Please you look at the sales } \\
\text { item. }\end{array}$ \\
\hline Total (\%) & \multicolumn{2}{|c|}{$10(21.73 \%)$} \\
\hline
\end{tabular}

Based on the data findings, addition errors is the third position occurd in this study. The forst one is the utterances "It sounds like fun.", whereas after the word "sound" it should be followed by adjective directly, it is not required to add the word "like" anymore.after it. Then the second sample is "We can see the beautiful view in there.", the word "there" shows the place instead, so the word "in" is not needed. And the last utterances of the sample in the Table 4 above is "Please you're look at the are sales item.", the EFL student add some words which is no required in this utterances. The word "are" must not appear in this sentence.

\section{The Misordering Errors}

The misordering errors are caused by incorrect placement of a morpheme or group of morphemes in a given utterance. Essentially, there are only four cases categorized as misordering errors. The following table will explain in the detail the findings on misordering error. Misordering errors is the least occured in this study. 
Journal of Education and Teaching Learning (JETL)

Volume 3, No 3, September 2021

Page 10-17

Table 5. Misordering Errors

\begin{tabular}{|l|l|l|}
\hline & \multicolumn{1}{|c|}{ Students' Utterance } & \multicolumn{1}{c|}{ Alternative Correction } \\
\hline & What price this is? & What price is this? \\
\hline Misordering Errors & I want to color black. & I want black color. \\
\hline & May I know who is this? & May I know who this is? \\
\hline Total (\%) & \multicolumn{2}{|c|}{$\mathbf{4 ( 8 . 6 9 \% )}$} \\
\hline
\end{tabular}

As seen in Table 5, the first sample is misordering of auxiliary verb, and the second sample is misordering of the noun namely, "I want to color black." it should be adjective followed by noun, not the other hand. And the last sample is "May I know who is this?", this misordering is incorrect placement of auziliary verb "is". So it means misordering of auxiliary verb occured twice in sample of Table 5 above.

\section{CONCLUSIONS}

This study focused on analyzing grammatical errors on EFL students' conversation practice. The participants of this study were the fourth term students of Indonesia Institute of Technology and Business, 2020/2021 academic year. The authors collected the EFL students' video recording of their conversation practice to analyze the data. The theory of surface structure taxonomy by Dulay, Burt, and Krashen (1982) and Tizazu (2014) categorized errors into four namely addition, omission, misformation and misordering.

Based on the data analysis and the discussion, it was clear that omission error is dominantly uttered by the participants, in other words 19 out of 46 cases belong to omission errors as the most frequently-occurred error committed by the EFL students' conversation practice. with the percentage $41.30 \%$. It is followed by misformation with total cases $28.26 \%$, addition with total cases $21.73 \%$, and the last followed by misordering with total cases $8.69 \%$.

It is suggested that the other reserachers or teachers can analyze other cases of grammatical errors. Because by analyzing this error the teacher would know the weaknesses of the students in facing learning English. So the teacher would be able to highlight the topic which becomes the frequently occured grammatical errors in the students' utterances especially when learning English as a foreign language.

\section{ACKNOWLEDGEMENT}

In accordance with the publishing of Journal of Education and Teaching Learning (JETL) in 2021, we would like to take this chance to thank you for your effort as a reviewer. This opportunity enabled us to meet the scheduled time and to maintain the standards of peerreviewed journals.

\section{REFERENCES}

Aziz, Z. A., Fitriani, S. S., \& Amalina, Z. (2020). Linguistic errors made by Islamic university EFL students. Indonesian Journal of Applied Linguistics (IJAL), 9(3), 733-745.

Dulay.H, Burt, M, \& Krashen,S. (1982). Language Two. Oxford: Oxford University Press.

Ellis, R \&Barkhuizen,G. (2005). Analysing Learner Language. Oxford: Oxford University Press.

Jabeen, A., Kazemian, B., \& Shahbaz Mustafai, M. (2015). The role of error analysis in teaching and learning of second and foreign language. Education and Linguistics Research, 1(2), 52-61. 
Journal of Education and Teaching Learning (JETL)

Volume 3, No 3, September 2021

Page 10-17

James,C. (1998). Errors in Language Learning and Use: Exploring Error Analysis. New York: Routledge.

Ruminar, H. (2018). Grammatical errors in ESP students' conversation practice across proficiency levels. EnJourMe (English Journal of Merdeka) : Culture, Language, and Teaching of English Vol. 3 No . 1 July (201 8 ) 15 - 22.

Rusmiati. (2019). Surface Strategy Taxonomy on Foreign Language Writing: A Study on Verb Tense Usage. Jurnal Serambi Ilmu, Volume 20, Nomor 2, Edisi September 2019, pp: 189-201.

Sadiah and Royani. (2019). An Analysis of Grammatical Errors in Students' Writing Descriptive Text. Project Professional Journal. Volume 2, No. 6, November 2019 pp 764-770.

Simbolon, M. (2015). An Analysis of Grammatical Errors on Speaking Activities. Journal on English as a Foreign Language, 5(2), pp: 71-86.

Srivastava, S.R. (2014). Accuracy vs Fluency in English Classroom. New Man International Journal of Multidisciplinary Studies, 1(4), pp: 55- 58.

Suhono. (2016). Surface Strategy Taxonomy On The EFL Students' Composition: A Study of Error Analysis. Iqra', Vol. 1, No. 2, November 2016 ISSN: 2527-4449.

Tizazu, Y. (2014). A linguistic analysis of errors in the compositions of Arba Minch University students. Advances in Language and Literary Studies, 5(3), 191-205.

Wati, A., \& Nursyaebah. (2017). No Title. An Analysis Of Grammatical Errors In Student' Writing Recount Text, 102. Jawa Timur: English Education Department. 